\title{
HOW TO CLASSIFY THE URBAN AREA? A PERSPECTIVE OF MULTI-CRITERIA APPROACH IN THE CONTEXT OF HYPER- DIVERSITY IN SETTLEMENTS IN GHANA
}

\author{
John E. K. AKUBIA ${ }^{1}$, Paul W. K. YANKSON ${ }^{2}$ \\ ${ }^{1}$ University of Trier, Trier, Germany, ${ }^{2}$ University of Ghana, Accra, Ghana

\begin{abstract}
Ghana is experiencing high population growth, rapid urbanization and a constantly accelerating growth of urban areas. Yet, the accurate delineation of urban settlements remains a major challenge faced by urban planners. While the emergent urban settlements are being characterized by highly-diverse, heterogeneous, and multiplicity of features, the need to rethink how best to classify new urban growth areas, beyond the commonly used population threshold of $\geq 5000$ inhabitants, is becoming increasingly inadequate. Thus, this paper proposes a multi-criteria approach, drawing on the concept of 'hyper-diversity'. Eight key dimensions - urban form, built-up extent, socio-economic functions, land-use dynamics, occupational structure, and governance structure and population size - were identified as a guide to the delineation of new urban settlements. Inferring these dimensions requires accurate spatial and statistical data on the prevailing land-use dynamics. Thus, the paper argues that analysing satellite-based remote sensing and ground truth-gathered data may provide standardized and timely information on the aforementioned dimensions. Applying this multi-dimensional approach may be useful for Ghana and similar countries where there is a lack of regular mapping of urban areas.
\end{abstract}

Key Words: urban classification, population size, hyper-diversity, satellite-based remote sensing, Ghana.

\section{Introduction}

Ghana, similar to many other countries in Sub-Saharan Africa (SSA), is experiencing a high population growth, rapid urbanization and a constantly accelerating growth of urban areas broadly defined as demographically large, relatively densely populated, built-up areas (Bloch et al. 2015). Following its independence in 1957, Ghana's rapid urban population growth in both absolute and relative terms has been accompanied by the expansion of the existing built-up areas and the emergence of new 'urban' areas (Ghana Statistical Service 2014). In 1960, when the first population and housing census $(\mathrm{PHC})$ was carried out by the Ghana Statistical Service - the institution responsible for delineating urban areas in Ghana, there were 98 estimated urban localities with an urban population of about 1.5 million people; by 2010 , when the last $\mathrm{PHC}$ was conducted, the number of urban localities (including towns, cities, municipalities and metropolis) had risen to more than 636 (Naab et al. 2013). A recent World Bank report showed that, at a growth rate of 4.4 per annum, the urban population growth has fast outpaced the rural population growth between 1984 and 2013, which is a clear indication that urban areas are expected to keep growing and increasing in numbers owing to the high natural population growth and to the in-migration, particularly from the rural hinterland (World Bank Group 2015).

Whilst the increase in urban areas play a key role in the spatial transformation processes of the country, their classification or delineations remain a major challenge faced by the urban planners and developers. Given that there is no universally-accepted approach, many countries, including Ghana, classify the urban areas, usually for PHC enumeration purposes, using a population threshold criterion. However, this approach has been questioned for various reasons. In the specific case of Ghana, the nature of urban growth makes the approach inadequate to describe what is classified as urban. The speed and degree of the urban growth, 
often preceding urban planning, has caused the spatial delineation of urban areas much more difficult to determine. It is worth noting that urban development in many parts of Ghana is mainly characterized by unregulated, fragmented, sprawling low-density growth and thereby it defies the geographical and administrative boundaries (Cobbinah and Erdiaw-Kwasie 2016). This makes it difficult to accurately delineate urban area boundaries for purposes of urban planning and management.

More so, a key characteristic of urban growth patterns as identified within the urban studies literature is the growing heterogeneity that exists in newly urbanizing areas. The changing spatial organisation alongside the rapid spatial transformation processes occurring within most cities in Ghana have caused a diversification in their urban form, reflecting the appearance of a multiplicity of functions, activities, social-economic realities and changing political and governance structures that were previously non-existent (Mahendra and Seto 2019). Today, urban areas have long emerged as engines of economic growth and nodes of development. With the ongoing massive urban transformation, new urban growth areas, especially growing peri-urban areas, are emerging as centers for education, employment, innovation, technological transfer, and as a ready market for manufactured goods and agricultural products (Dodier 2013, Rickards et al. 2016, lossifova et al. 2018). In view of this, the single populationbased classification criterion does not adequately capture the areas that are currently urban or urbanizing.

Whereas PHC data collected on a decadal basis consistently provide key information about urban areas in Ghana, the reliance on such data has become insufficient due to the growing heterogeneity and multiple features characterizing urban areas (Elmqvist et al. 2018, Keil 2018, Mahendra and Seto 2019). The main challenge associated with such data is the long period of time over which they are collected which implies that they not only get quickly out-dated but they also fail to keep pace with the rapid urban development, in particularly, of areas outside the official urban boundaries such as growing urban areas which are rapidly absorbed into towns without any statutory status. These concerns have been buttressed by Songsore (2009) who described the population-based approach as very narrow and a contributory factor to unsustainable spatial development patterns being experienced by cities in Ghana. Considering the apparent challenges and difficulties associated with the use of the population threshold of five thousand or more people to classify urban areas, the mandated institutions and urban scholars across the country have been increasingly preoccupied with determining how best to accurately classify urban areas in a timely and efficient manner (Owusu 2008, Ghana Statistical Service 2014). It is understandable that a multi-criteria approach can guide not only the accurate classification of urban areas but also it can help in identifying the multiple factors driving the development of new urban areas, it can better monitor the change processes from rural to urban, and it can assess the links between the scale and type of urban growth, and the spatial development patterns while urban growth is more accurately characterized.

Various scholars have attempted to standardize the delineation of urban areas in remote sensing data. However, the lack of universally accepted spatial-statistical dimensions (Moehl et al. 2016) coupled with the use of different types of satellite imagery, different classification schemes and different scales of analysis, has made a commonly accepted classification of urban areas difficult to achieve. As noted by Møller-Jensen et al. (2020), most remote sensing studies, through satellite-based classifications, have provided up-to-date and accurate information about the extent of urban growth, but yet there is neither a universally agreed definition nor a classification approach of urban areas. Consequently, information on what defines an urban area and/or how to classify areas that have attained the urban status is conceptually and practically lacking. Therefore, the aim of this paper is to focus primarily on exploring and identifying a multi-dimensional approach as a feasible alternative to guide both the classification and the mapping of urban areas in Ghana. We do this by addressing the question: How best can we classify urban areas beyond the conventional population-based or 
administrative criterion in Ghana? We addressed this question by drawing on the concept of hyper-diversity as propounded by Tasan-Kok et al. (2013). By widening the focus to encompass the diverse, multi-dimensional attributes and spatially differentiated conditions which characterize and reflect the status quo qualities of newly developing urban areas (Vertovec 2007, Schmid et al. 2018), the hyper-diversity perspective provides an understanding that goes beyond the population-based classification of new urban areas.

\section{Classifying urban areas using the minimum population threshold}

The minimum population threshold (MPT) is the most widely used criterion to distinguish urban localities from rural localities across different countries. Reports compiled by the United Nations Population Division (United Nations 2018) indicate that 101 countries use the MPT to classify urban settlements (Deuskar 2015). The thresholds used vary from country to country. In Denmark and Sweden, the minimum population size is 200; in Canada and Australia, it is 1000; in United States and Mexico, it is 2,500; in Ghana and Nigeria, it is 5000; and in Japan, it is as high as 30,000 (United Nations 2018).

Despite its wide and continuous usage, the MPT is not a satisfactory criterion for classifying urban areas, especially in highly industrialised countries (Dijkstra and Poelman 2014, Deuskar 2015). For this reason, some countries have taken other dimensions such as prevailing landuse patterns and other socio-economic conditions into consideration (Uchida and Nelson 2009).

More so, there are widely reported weaknesses associated with the MPT criterion for determining urban areas (Baker and Pedersen 1992, Songsore 2009, Ghana Statistical Service 2014, Deuskar 2015). A major limitation of the MPT criterion originates from the numerous errors associated with censuses through which population data is captured. According to Hansen et al. (1953), population censuses almost always have inherent errors such as sampling errors, response errors, compilation errors, errors due to the chosen methodology and inappropriate definitions. These errors produce spurious population figures that are not a true reflection of the actual population size of a given locality. This leads to misclassifications of settlements and so we argue that population size as a sole criterion is not adequate for the accurate classification of urban settlements.

The spatial organization of emergent urban settlements exhibit diverse dimensions (Schmid et al. 2018) that are worth considering. In particular, the spatial aspects provide useful insights into the dynamic nature of new urban areas. This may explain the emergence and rapid growth of the urban land-use science community (Gamba and Herold 2009, Bhatta 2010, Rashed and Jürgens 2010, Seto et al. 2012, Kleemann et al. 2017). These experts have variously applied geospatial data, tools and techniques to detect and map urban areas. A criterion in this direction would be a very useful complement for the population-based criterion.

More so, to identify the key and salient features of a new urban phenomenon, urban scholars and planners would have to consider the frontiers of emergent urban structures - peri-urban ${ }^{1)}$ areas (Adam 2014). It is important to note that the ongoing urban expansion in most cities in Ghana concentrates at the periphery. Yet, these areas, although characterized by low population densities, exhibit several conditions which are urban in character (Kleemann et al. 2017). Given the growing materializations of the diverse urban conditions at the periphery, Gough and Yankson (2006) have suggested that peri-urban areas should be considered as an extension of the urban rather than an entirely distinct area. In Møller-Jensen et al. (2020), the

1) Peri-urban is used in this paper to refer to the land around the edges of an urban area, either just within or beyond urban boundaries, where land use patterns are often in the process of changing from more rural (agriculture) to more urban (buildings). 
analysis of the urban land-use dynamics showed that the rapidly developing settlements at the periphery are dominated by urban housing (and related infrastructure and services) and they are occupied by urban residents engaged in urban livelihood activities.

\section{Current definition and classification of urban settlements in Ghana}

In Ghana, urban areas are defined as settlements with a threshold population of 5000 or more (Ghana Statistical Service 2014). According to the data and statistics (Fig. 1) provided by the United Nations (2018), Ghana's population growth and urbanization experienced a trend of steady increases. With a current urbanization level of $56 \%$, it is reasonable to assume that as the pace of urbanization accelerates, so that the number of urban settlements keeps increasing. In fact, smaller towns and cities are observed to have experienced the fastest rate of urban growth over the last couple of years (World Bank Group 2015). Forecasts also show that the number of urban settlements in the country may increase massively in the coming decades. As new and existing localities such as large villages, hamlets and rural enclaves grow to exceed 5000 inhabitants, they are classified as urban areas.

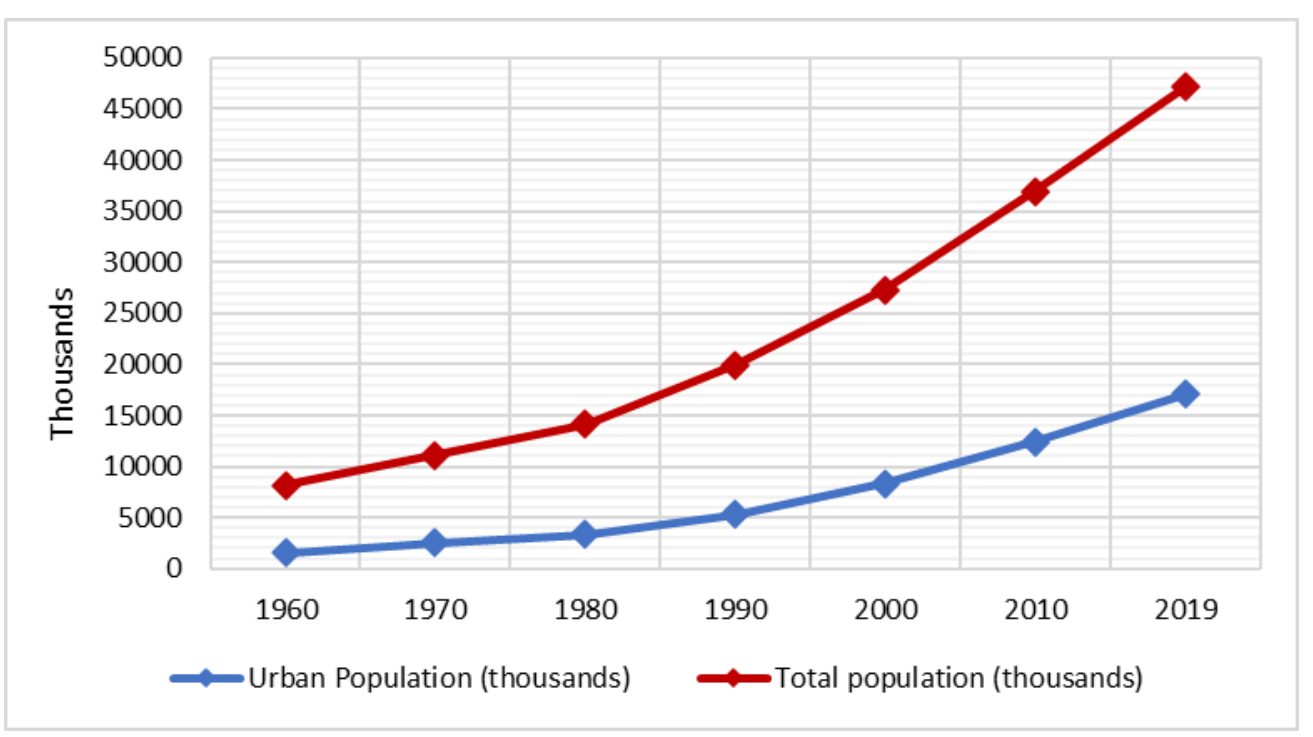

Fig. 1 - Trends in population growth and urbanization in Ghana (1960-2019) Source: United Nations (2018)

As indicated by a recent World Bank report, "the number of medium (20,000-50,000 people) and large medium $(50,000-100,000)$ sized towns have over the years quadrupled and tripled, respectively" (World Bank Group 2015: 2). The main factors driving urban growth and increases in urban settlements are: governmental policies (such as decentralization), natural population increase in urban areas, rural-urban migration, and the immigration from other countries (Ghana Statistical Service 2014). Whilst these factors contribute to the distribution of the population, they are also responsible for the growing diversity characterizing the emergence of new urban settlements.

At the core of Ghana's ongoing urbanization dynamics, the emergence of new urban growth can be observed at several levels. These include mainly conurbations, urban agglomerations, 
secondary cities, and the merging of towns and villages. Currently, there are neither published data nor a full list with the precise number of urban settlements in Ghana. However, according to Potts (2018), as of 2020, there were 257 small 'Class 8' settlements which had populations between 5000 and 10,000 people. It was also noted that 70 of these settlements were classified as rural in the previous PHC in 2000. A recent up-to-date database produced by SWAC (2020) revealed the total number of urban agglomerations in Ghana to be 209 (Fig. 2) as of 2015. This is an increase from 87 urban agglomerations established in 1990 (SWAC 2020). It is believed that much of this urban agglomeration growth occurred from the emergence of smaller agglomerations with populations between 10,000 and 50,000 inhabitants. Besides, a 2019 map data obtained from the Ghana Statistical Service (2014) shows 219 major urban localities in Ghana. Taking this together, it seems clear that the identified number of urban localities does not commensurate the Ghana's level of urbanization. As noted by Potts (2018), the precise number of urban areas is not easily ascertained.

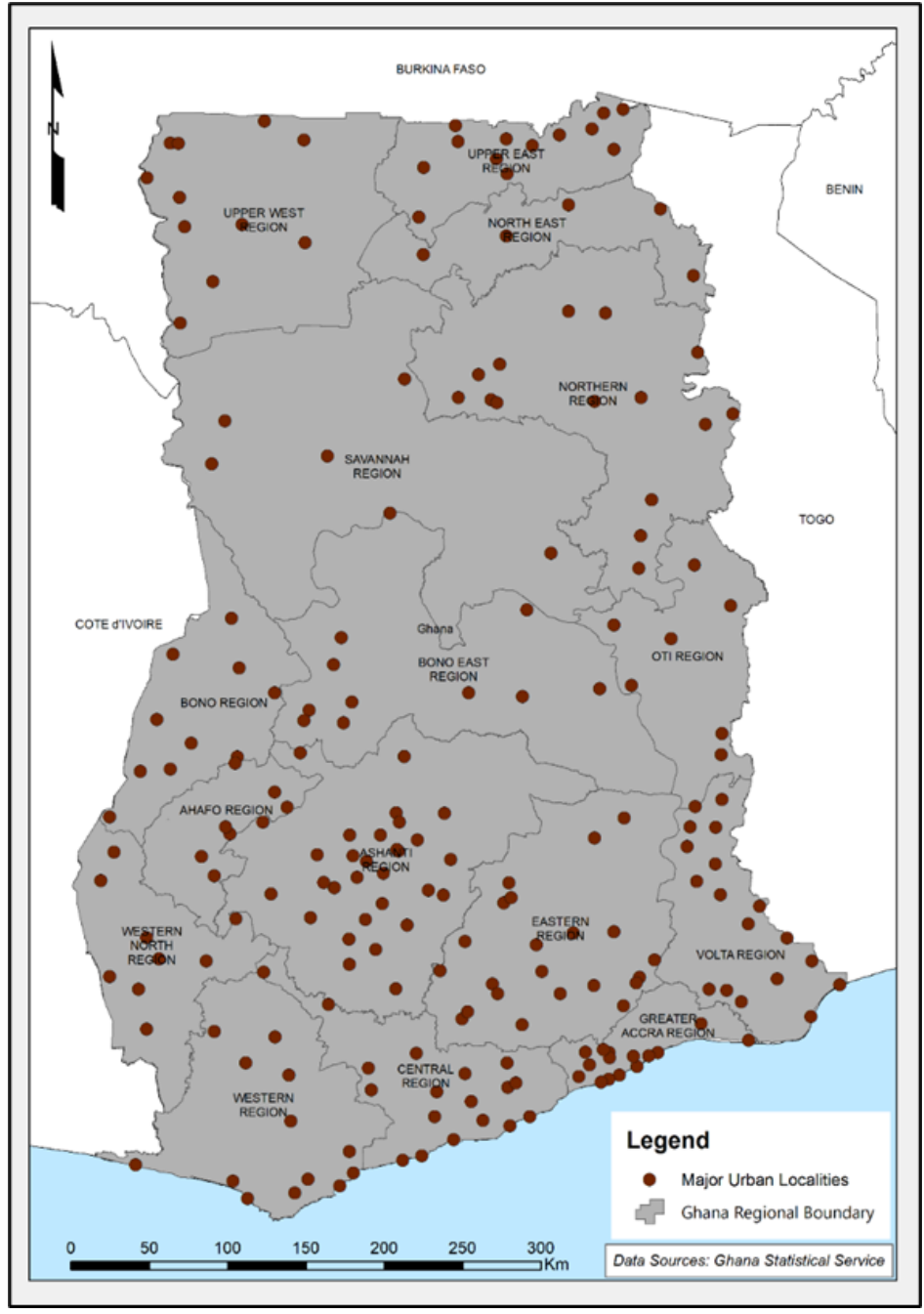

Fig. 2 - Map of

Ghana showing the major urban localities in a regional context 
Quite a number of urban remote sensing studies (Oduro et al. 2014, Angel et al. 2016, Benza et al. 2016, Appiah et al. 2017, Møller-Jensen et al. 2020) have revealed a significant urban growth and steady increases in the urban settlements' patterns in Ghana. However, doubts have been casted on the data on the country's level of urbanization as well as on the quantum of urban areas being produced by various studies (Potts 2018, Møller-Jensen et al. 2020). The fact that settlements in Ghana are classified or delineated as "urban" purely on the population size (a threshold of 5000 people) has been the subject of concern among some Ghanaian urbanists. At the 'First International Conference on Urbanization and Rural-Urban Migration in sub-Saharan Africa' held in Nairobi (2012), there has been the argument that the 5000 threshold is misleading due to a number of limitations. It asserted that the approach has led to the spurious classification of settlements which were still largely villages in their socioeconomic characteristics. Potts (2018) concurs, arguing that a threshold of 5000 has become less reliable to distinguish between 'rural' and 'urban' settlements in an economic function sense. This is because it is observed that although localities may easily attain the 5,000 threshold to be qualified as urban, they may maintain their rural outlook based on the predominant economic activities (Ghana Statistical Service 2014). This is an indication of the tendency to overestimate both urban population figures and the number of settlements that are re-classified as being urban. As argued by Potts (2018), without the inclusion of erroneously classified 'urban' villages, Ghana should probably not, as yet, be regarded as half urban.

Although PHC data tend to be regularly available, i.e. every ten years, the long gaps between the census years often result in the misrepresentation and over-generalization of urban growth. This undoubtedly can lead to the spurious delineation of urban settlements. A major challenge in this regard can be due to the expansion of urban areas beyond the administrative boundaries into rural settlements. This is evident in some census reports where some relatively large urban localities, which form a part of municipal and metropolitan areas, were found to have engulfed 'rural' areas.

Taking into consideration Ghana's rapid urban growth in terms of both population and area, the use of the population size criterion alone to classify an urban locality has become both problematic and inadequate (Ghana Statistical Service 2014). The approach was adopted and used for the first post-independence census in Ghana in 1960. During this period, the total population found in the settlements was usually low (Potts 2018). At this point in time, the threshold of 5,000 was not only more reliable and sufficient, but also convenient to delineate the urban settlements. So far, Ghana has conducted five PHC (1960, 1970, 1984, 2000 and 2010). Yet, the population size criterion alone is still being used today (Szabo 2016). With the high population growth taking place today, coupled with the rapid merging of hitherto scattered rural localities and forming agglomerated urban settlements, a threshold of 5,000 has become very unreliable and inadequate to delineate urban localities from rural areas (Potts 2018).

Although population data provide information on the size of the urban population, information on the spatial (geo) location of urban areas remains difficult to obtain (Moriconi-Ebrard et al. 2016). It is important to state that urban settlements differ in size, form, configuration, as well as different socio-economic structures, thus applying one sole criterion in their classification impedes cross-regional comparisons. For instance, the current classification approach of the 'urban' neither denotes the spatial extent nor the geolocation of areas classified as urban. This makes the comparative regional analysis of trends and patterns of urban growth difficult. More so, the data on population size do not provide key information on the spatial variation in the size of different urban settlements.

In addition, the criterion does not offer any means to delineate urban hierarchies in different regions of Ghana (Owusu 2005). For instance, categories such as 'small', 'medium' and 'large' are undefined by the MPT criterion. Although urban localities in Ghana have been graded 
according to the following categories: 5,000-9,999 people, 10,000-19,999 people, 20,00049,999 people, 50,000-99,999 people, and 100,000 people and over (Yeboah et al. 2013), there is no accompanying description. Thus, such categorizations are deemed vague. Lastly, the 'urban' classification approach being used counts the floating population, creating a spatial mismatch that introduces a bias (Weeks 2010). During the census, people are enumerated at wherever they were on the census night and not at where they usually resided (Ghana Statistical Service 2014). In the context of current urban development patterns, the majority of people stay overnight in the peri-urban settlements (Doan and Oduro 2012, Gough et al. 2015), but they commute to the central business district to work. Yet, given their very low population densities, peri-urban areas are not considered as urban as far the population-based criterion is concerned. Therefore, the probability of miscounting or under-counting due to the unpredictable movement of people is high. Against this backdrop, the Ghana Statistical Service (2014) has admitted that the population-size criterion alone is unsatisfactory for classifying the urban settlements and, therefore, it argues for other considerations based on the settlements' functions and primary socio-economic activities (Ghana Statistical Service 2014).

Given the limitations and challenges associated with the MPT criterion, the authors argue that a multi-criteria approach may be more appropriate in the classification of 'urban' settlements in Ghana. The evolution of urban settlements has generated important salient functions based on spatio-economic processes, structures and features that can be considered in addition to population data to classify urban localities. As noted by Schmid et al. (2018), as urban settlements grow and expand, spatial structures and processes, in terms of economic, social, political and demographic changes, materialize. These dynamics can be regarded as both new urban conditions and desirable outcomes of urban development - referred to by Vormann (2015) as urban diversity. Vormann (2015) describes diversity as one of the main features of modern cities, denoting a situation of multiplicity and heterogeneity. As spaces of agglomerations, conurbations and intersections, urban areas are often at the centre of debates and discourses on diversity. Within this context, we reckon that the novel and classical idea of hyper-diversity (Tasan-Kok et al. 2013) grants us insights into the normative dimensions engrained by urban development processes.

\section{Manifestations of hyper-diversity in urban settlements}

Hyper-diversity of urban spaces is reflected in the evolving heterogeneity of cities (KorcelliOlejniczak 2017). With heterogeneous features and distinguishing characteristics manifesting, the reliance on one criterion (population size) for distinguishing urban areas may thus become less reliable. As Schmid et al. (2018: 21) state, "the urban world has fundamentally changed in the last decades whereby varied urbanization processes and conditions have characterized urban landscapes". In particular, urban areas have become very dynamic and heterogeneous in terms of demographics, functions, spatial structures, socio-economic and employment and lifestyles among others (Schmid et al. 2018). This is consistent with the hyper-diversity concept of Tasan-Kok et al. (2013). Hyper-diversity broadly includes the "intense diversification of the population in socio-economic, social and ethnic terms, but also with respect to lifestyles, attitudes and activities" (Tasan-Kok et al. 2013: 6). This perspective has given us insights into the heterogeneous and multi-dimensional characteristics of urban settlements (Schmid et al. 2018).

The main argument we make for 'urban' hyper-diversity is that towns and cities in Ghana and elsewhere are not homogeneous spaces. They originate differently, perform different functions and exhibit a wide range of features. Thus, the attempts of statistical authorities to classify the urban localities by using a single criterion simply fail to consider relevant heterogeneous dimensions (Pitter and Lorinc 2016). Elaborating on the context-specific concept of 'urban' hyper-diversity, Korcelli-Olejniczak (2017) explained that the spatial organization of towns and 
cities is characterized by numerous inter-related features.

Three salient features underscored by hyper-diversity in Tasan-Kok et al. (2013) and KorcelliOlejniczak (2017) are particularly relevant in guiding us to identify and to take into account the meaningful dimensions in measuring what is 'urban'. The choice of this concept as an entry point towards identifying urban dimensions is premised on three key issues. Firstly, the notion evades the simple classification of urban areas based on the MPT. Secondly, the concept provides insights into very different aspects of socio-economic, socio-demographic, ethnic and cultural diversity as the emerging 'urban' conditions and they are generally viewed as desirable dimensions to consider in classifying urban settlements. Thirdly, the perspective places an emphasis on the multi-dimensional features that strongly characterize the development of urban areas.

More to the point, the concept of hyper-diversity triggers a thinking that does not oversimplify the urban. Rather, it emphasizes the realities of the structures and processes that unfold to shape the spatial organization of urban areas. From this perspective, we argue that the hyperdiversity notion can capaciously be used to rethink how urban areas grow and expand with regard to the dynamic structures and processes within which individuals, households, communities and institutions continually and increasingly distribute themselves (Colomb and Raco 2015). We, therefore, draw on the notion of hyper-diversity as a conceptual and theoretical perspective to gain an understanding of the multi-dimensions that can aid in classifying urban settlements.

As already noted, Ghana's urban population is highly diversified and as such urban settlements are evolving in ways that require a multi-criteria approach to accurately delineate and classify the 'urban' localities from the surrounding rural areas. The idea of hyper-diversity provides a logical understanding of the many ways of conceptualizing and defining the 'urban' beyond the number of the inhabitants in a given area. Importantly, the key structural economic and spatial changes, social and political factors, as well as the forms and patterns of urban development (Gough et al. 2015) provide an excellent lens through which a multi-dimensional criterion can be ascertained to guide the classification of urban areas.

\section{Methodology}

In order to identify the concrete dimensions typifying the emergent urban settlements in Ghana, we carried out a comprehensive review and synthesis of the literature. The findings from the existing studies including scientific publications, peer-reviewed articles, theses and dissertations, working papers, conference materials and other grey literature, were accessed mainly from Web of Science, Annual Reviews and Google Scholar. These online databases were searched using combinations of keywords: urban, what-is-urban?, how-do-we-define-ormeasure 'the urban'?, urban-classification-systems, urban-hyper-diversity, urban-dimensions, and determining-urban-settlement. By focusing on these content-related search terms, we sought to explore the key data and information for our topic. The selected texts, documents and scientific materials were stored in the Citavi for Windows version 5.7. This was used to organize the texts and knowledge as well as to manage the reference citations. At least 124 papers were reviewed out of which eight overarching, causally related urban dimensions were derived. Overall, these dimensions provide the key baseline information which can aid in determining the urban in Ghana.

\section{Results and Discussion}

The dimensions noted in Table 1 reflect a vivid illustration of urban hyper-diversity. The notion requires us to acknowledge that 'urban' spaces contain multiple and heterogeneous conditions. 
Thus, by using a hyper-diversity lens, we are able to identify other criteria to measure what is urban. In addition to the highlighted dimensions, various other possible dynamic attributes of human settlements can be considered a categorization and delineation of the urban. These include: lifestyles, attitudes, household income levels, access to core urban services and activities. Whilst, the highlighted dimensions prove to be key factors to enhance how urban areas are identified and classified, and analyzing such functional, structural and morphological changes requires data on the urban settlements and populations. Yet, compiling urban data in Ghana remains a major challenge. In fact, the lack of accurate and timely local data brings severely constraints for the estimations of urban settlements.

\section{Dimensions portraying hyper-diversity in urban settlements in Ghana}

\begin{tabular}{|c|c|c|}
\hline Dimension & $\begin{array}{c}\text { Key findings derived from the supporting litera- } \\
\text { ture }\end{array}$ & Source \\
\hline $\begin{array}{l}\text { Urban } \\
\text { form }\end{array}$ & $\begin{array}{l}\text { Urban form refers to the broad spatial } \\
\text { characteristics of an entire urban region including } \\
\text { the shape, distribution, patterns and arrangement of } \\
\text { urban complexes that represent the urban land use } \\
\text { within the region. } \\
\text { - Ghana is experiencing a rapid outward } \\
\text { expansion of urban development (urban sprawl). } \\
\text { - With the growing dispersion of people, activities, } \\
\text { institutions and resources, urban spatial } \\
\text { transformation has been traditionally } \\
\text { characterised by a shift from monocentric to } \\
\text { polycentric patterns. } \\
\text { New trends, patterns and processes regarding } \\
\text { peri-urbanization are manifesting and, similarly, } \\
\text { new urban settlements are materializing. } \\
\text { Therefore, the urban form may be a useful } \\
\text { criterion for classifying the urban status. }\end{array}$ & $\begin{array}{c}\text { Asiedu and Arku } \\
\text { (2009), Gough and } \\
\text { Yankson (2011), Doan } \\
\text { and Oduro (2012), } \\
\text { Owusu (2013), Benza } \\
\text { et al. (2016), } \\
\text { Kleemann et al. (2017) }\end{array}$ \\
\hline $\begin{array}{l}\text { Extent of } \\
\text { built-up } \\
\text { area }\end{array}$ & $\begin{array}{l}\text { 'Built-up areas' refer to the areas covered with and } \\
\text { used for residential, industrial and commercial } \\
\text { buildings and infrastructure, and other urban } \\
\text { structures. } \\
\text { - The rapid increase in built-up areas is driven by } \\
\text { the increasing demand for housing and the } \\
\text { related infrastructure and services by urbanites. } \\
\text { - Current urban development patterns are char- } \\
\text { acterized by the spontaneous proliferation of } \\
\text { large-scale built-up areas with an expansive } \\
\text { spatial distribution of massive residential devel- } \\
\text { opments. } \\
\text { The extent and pattern of built-up areas is thus } \\
\text { a key dimension of urban landscapes. The set- } \\
\text { tlements with contiguous patches of built-up } \\
\text { land greater than } 1 \mathrm{~km}^{2} \text { each could be a rele- } \\
\text { vant criterion for classifying the urban areas. }\end{array}$ & $\begin{array}{l}\text { Schneider and Wood- } \\
\text { cock (2008), Doan and } \\
\text { Oduro (2012), Gough } \\
\text { et al. (2015), Appiah et } \\
\text { al. (2017) }\end{array}$ \\
\hline
\end{tabular}




\begin{tabular}{|c|c|c|}
\hline $\begin{array}{l}\text { Land-use } \\
\text { dynamics }\end{array}$ & $\begin{array}{l}\text { In the context of classification, this means a human } \\
\text { use of the land for different purposes that are } \\
\text { characteristically urban. It encompasses diverse } \\
\text { and mixed uses of land within an urban scene. } \\
\text { - The rapid sprawl of urban core cities into } \\
\text { peripheral zones is transforming land use. There } \\
\text { are diverse, multi-functional uses of land on the } \\
\text { periphery of Ghana's major cities. } \\
\text { - Land-use diversity signifies urban development. } \\
\text { Thus, heterogeneous, rapidly changing land-use } \\
\text { may be a suitable criteria for classifying the } \\
\text { urban status. } \\
\text { - Advances in satellite-based remote data and } \\
\text { technology, as well as in algorithm development, } \\
\text { have allowed scientists to classify urban } \\
\text { settlements based on land use features. }\end{array}$ & $\begin{array}{c}\text { Gough and Yankson } \\
\text { (2000), Owusu (2013), } \\
\text { Seto and Reenberg } \\
\text { (2014), Appiah et al. } \\
\text { (2015), Oduro et al. } \\
\text { (2015), Angel (2016), } \\
\text { Stow et al. (2016), } \\
\text { Appiah et al. (2017) }\end{array}$ \\
\hline $\begin{array}{l}\text { Socio- } \\
\text { economic } \\
\text { functions }\end{array}$ & $\begin{array}{l}\text { The services, activities, systems and institutions } \\
\text { contributing to the dynamics of settlements. } \\
\text { - In Ghana, urban expansion (including population } \\
\text { increase) in peri-urban spaces involves a } \\
\text { de-concentration of core urban functions (e.g. } \\
\text { services, residential, administrative etc.). } \\
\text { - Small peripheral towns and villages are rapidly } \\
\text { assuming the urban status due to the } \\
\text { coalescence and strong presence of social and } \\
\text { economic activities, systems and institutions. } \\
\text { - Thus, an urban status classification scheme } \\
\text { could consider the presence and availability of } \\
\text { local government offices, markets and shopping } \\
\text { centres, health facilities, hotels, transport, } \\
\text { factories, energy consumption, schools. }\end{array}$ & $\begin{array}{c}\text { Yeboah et al. (2013), } \\
\text { Ghana Statistical } \\
\text { Service (2014), Gough } \\
\text { et al. (2015) }\end{array}$ \\
\hline $\begin{array}{l}\text { Occupa- } \\
\text { tional } \\
\text { structure }\end{array}$ & $\begin{array}{l}\text { It covers the predominant employment status, and } \\
\text { the occupation type, including technical and } \\
\text { vocational professions, in a given locality. } \\
\text { - In Ghana, the outward expansion of cities } \\
\text { changes the occupational structure of peri-urban } \\
\text { areas. } \\
\text { - There has been a massive shift from rural, } \\
\text { agricultural, activities to service activities in } \\
\text { urban areas. Manufacturing is increasing the } \\
\text { fastest in peri-urban areas. } \\
\text { - Therefore, the urban status can be categorized } \\
\text { by considering the main economic activities of } \\
\text { the population and of each locality. }\end{array}$ & $\begin{array}{c}\text { Bawakyillenuo et al. } \\
\text { (2013), Ghana Statisti- } \\
\text { cal Service (2014), } \\
\text { Gough et al. (2015), } \\
\text { World Bank Group } \\
\text { (2015) }\end{array}$ \\
\hline
\end{tabular}




\begin{tabular}{|c|c|c|}
\hline $\begin{array}{l}\text { Population } \\
\text { size }\end{array}$ & $\begin{array}{l}\text { The conventional criterion for classifying urban set- } \\
\text { tlements. } \\
\text { - A large population size corresponds with a high } \\
\text { urbanization, resulting in the rapid conversion of } \\
\text { rural to urban areas (re-classification). } \\
\text { - Villages and small towns are rapidly attaining } \\
\text { the MPT of } 5000 \text { people due to the natural } \\
\text { population increase. } \\
\text { - Population size is the most convenient criterion } \\
\text { for determining urban settlements. It can be } \\
\text { enhanced by integrating other dimensions too. }\end{array}$ & $\begin{array}{c}\text { Doan and Oduro } \\
\text { (2012), Ghana } \\
\text { Statistical Service } \\
\text { (2014), Oduro et al. } \\
\text { (2014) }\end{array}$ \\
\hline $\begin{array}{l}\text { Govern- } \\
\text { ance } \\
\text { structure }\end{array}$ & $\begin{array}{l}\text { The institutional political structures, mechanisms } \\
\text { and processes through which decision-making, the } \\
\text { use of resources and service provision are } \\
\text { achieved in a political area. } \\
\text { - Following the decentralization in 1988, the local } \\
\text { government in Ghana has proliferated in line } \\
\text { with the rapid urbanization and urban growth. } \\
\text { New settlement areas have rapidly been } \\
\text { converted into economic, political and } \\
\text { administrative units. } \\
\text { - In expanding peri-urban areas, state-led } \\
\text { governance systems exist alongside informal } \\
\text { actors (including community actors and } \\
\text { traditional leaders, the private sector and civil } \\
\text { society organizations). } \\
\text { - The presence of local government structures, } \\
\text { institutions and offices may serve as a useful } \\
\text { justification for delineating a given area as } \\
\text { urban. }\end{array}$ & $\begin{array}{c}\text { Owusu (2008, 2013, } \\
\text { 2015), Ghana } \\
\text { Statistical Service } \\
\text { (2014), Cities Alliance } \\
\text { (2017) }\end{array}$ \\
\hline $\begin{array}{l}\text { Housing } \\
\text { structure }\end{array}$ & $\begin{array}{l}\text { Housing structure is an indicator of the general } \\
\text { income and living standards of the residents. It also } \\
\text { includes the level of infrastructure in a given } \\
\text { settlement. } \\
\text { - Massive growth in peri-urban areas is character- } \\
\text { ized by new middle-class housing settlements. } \\
\text { - Almost all houses built in peri-urban areas are } \\
\text { constructed using materials permitted for urban } \\
\text { housing by the Ghana Building Code } 1988 \text {. } \\
\text { - Importantly, housing structure could serve as a } \\
\text { criterion for classifying an area as urban if there } \\
\text { are high-quality housing units built with materials } \\
\text { stipulated by the Ghana building code for urban } \\
\text { houses. }\end{array}$ & $\begin{array}{c}\text { Møller-Jensen and } \\
\text { Knudsen (2008), } \\
\text { Gough and Yankson } \\
\text { (2011), Doan and } \\
\text { Oduro (2012), Yeboah } \\
\text { et al. (2013) }\end{array}$ \\
\hline
\end{tabular}




\begin{abstract}
At this point, we reckon that only a geospatial approach can directly and indirectly help to detect spatial and statistical data on urban settlements. In principle, a geospatial approach that combines satellite-based remote sensing data with urban demographic, socio-economic and actual land use characteristics can help discover both the location of existing and of newly urbanized areas and their sizes. This approach allows for a verification of the existence, or lack thereof, of an urban settlement based on the dimensions and associated indications. It is further argued that satellite-based classification of 'urban' land-use dynamics reinforced by ground truthing proves to be an objective method to classify urban areas. This is because landuse dynamics expresses the most visible form of a settlement's transition from rural to urban. In other words, the urban scene is composed of easily detectable spatial structures (patterns, forms, layout and distribution of geographic phenomena), and spatial processes (mechanisms producing spatial structures). Thus, the spatial and temporal dynamics of land-use effectively portrays the manifold dimensions underpinning the spatial development of any urban settlement (Adam 2014). Within this context, this study defines urban settlements as a heterogeneous and multi-dynamic geographical area, with increased human-made structures over time and a land-use system that encompasses all basic services and facilities underpinned by social, economic, political, demographic processes and functions. From this definition, we draw attention to the fact that the 8 highlighted dimensions can be detected based on the prevailing uses of land within a particular settlement. This is equally based on the premise that the spatial development of the settlements in inextricably linked to the use of land.
\end{abstract}

As noted earlier, the use of geo-information techniques has already become a widely adopted approach to land related data analysis. Therefore, the relation between the highlighted dimensions and the land use dynamics can be established based on satellite data, ground-truth assessments and the selection of training sites. For instance, an urban status classification could be done based on the functions performed (and services provided) in a given settlement. Such functions and services can be ascertained based on the prevailing land use dynamics in the area. Thus, data on basic spatial structures related to each of the identified dimensions can be gathered, mapped and combined with the MPT of 5,000 people in order to classify a locality as urban. Given that satellite-based remote sensing data offer a unique assistance to measure what is urban based on physical land features, we expect that urban remote sensing scientists can develop algorithms that can infer the basic structures and processes of the proposed dimensions to classify urban areas. We believe this is consistent with the quest to standardize the definition of the urban using remote sensing data (Mahendra and Seto 2019).

\title{
Classification of urban areas by satellite-based remote sensing data and techniques
}

Given the near accurate change detection of land-use features, the classification of urban and non-urban areas is emerging from work using GIS and remote sensing (Kleemann et al. 2017, Mahendra and Seto 2019, Møller-Jensen et al. 2020, for recent examples). The analysis of high-resolution satellite imagery and of other spatially explicit data provides detailed information on the urban land uses and it reveals urban forms, built infrastructure, socio-economic functions and activities, the presence of truck infrastructure, the seemingly urban residential buildings, and the availability of core urban services (Mahendra and Seto 2019).

There have been many studies that looked at classifying urban areas using different satellitebased remote sensing data and at different scales. Some examples are Donnay et al. (2001), Bhatta (2010), Griffiths et al. (2010), Mahendra and Seto (2019). In Ghana, for instance, Kleemann et al. (2017) used cloud-free high-spatial-resolution satellite data provided by Digital Globe via Google Earth to identify the patterns of urban development in Takoradi and Bolgatanga. In another study, Benza et al. (2016) also used Landsat Enhanced Thematic Mapper Plus (ETM+) and European Remote Sensing Satellite-2 (ERS-2) synthetic aperture radar (SAR) imagery to define the urban-based on land use and land cover. This enabled the 
delineation of nine urban patches which were triangulated with census derived population size (Benza et al. 2016). Putting together a database, SWAC (2020) applies spatio-statistical criteria to the delineation of urban agglomerations. Its geospatial standardized database combines demographic data, satellite and aerial imagery and other cartographic sources to carry out a comprehensive assessment of ongoing processes of urbanization and spatial development dynamics in Africa.

Although remote sensing is useful for mapping and classifying urban areas, some limitations exist. Firstly, the heterogeneity of urban settlements coupled with characteristics of the consistently available low-medium resolution Landsat-Tm makes the delineation of urban areas quite difficult but not impossible (Mahendra and Seto 2019, Møller-Jensen et al. 2020). It is noted that despite its capability of providing consistent information on land features, built-up form and configuration, some human settlements are really difficult to discern from space. Whilst satellite-based data is limited by the remote sensing scientist's knowledge of ground conditions. A major challenge in this regard is represented by the variations in object reflectance and the inability of some single remote sensing sensors to differentiate across land surface features. Thus, processing, analysing and classifying SRS images of urban areas may be limited due to the difficulties associated with their multi-sensor, multi-temporal and multimodal nature and the sources of data. Integrating or fusing multi-source satellite data is a complex and time-consuming task (Donnay et al. 2001). To surmount these challenges, geospatial analysts and urban land-use scientists advocate for the application of segmentation and mosaicking techniques (see for example Rashed and Jürgens 2010). According to Estes et al. (2018) and Møller-Jensen et al. (2020), object-oriented segmentation and/or classification of very-high spatial resolution imagery produces accurate and favourable results rather than a per -pixel classification. Technically, object-oriented classification allows the integration of multiple non-spectral information on the structure and characteristics of urban areas (Estes et al. 2018). Yet, also, a fundamental problem associated with this approach is that while there is often a relatively simple, direct relationship between the land-cover type and the detected spectral reflectance, the same cannot be applied to land-use dynamics. Land-use is considered an abstract amalgamation of cultural and economic factors (Seto et al. 2012, Mahendra and Seto 2019), most of which cannot be determined directly by remote sensing. However, different types of urban land-uses reflect a characteristic spatial pattern of a spectrally distinct land cover, which then enables their recognition in high spatial resolution SRS images (Estes et al. 2018).

To improve the detection and delineation of urban areas based on land features, it may be necessary to integrate SRS data from modern imaging spectrometers, such as the Environmental Mapping and Analysis Program (EnMAP, Kaufmann et al. 2016). The development and intensified use of imaging spectrometers or hyper-spectral imaging to record multi-temporal SRS data at short intervals and at high spatial and spectral resolution open up new possibilities to effectively detect land-use patterns within urban settlements (Guanter et al. 2016). EnMAP combines excellently with multi-spectral satellite systems, such as IKONOS and Quickbird, to assess the spatial and temporal diversity of changing in urban land use dynamics (Kaufmann et al. 2016), which is the focus of a successive study being carried out by the authors.

\section{Conclusions}

The aim of this paper has been to explore how best the classification of urban areas in Ghana could be performed. This has been based on the premise that population size alone is no longer reliable to classify an urban area due to increased populations, changes in spatial development patterns and, of course, the accelerating growth of urban areas over time and space. Drawing inspiration from the concept of hyper-diversity in settlements, our review and synthesis of the literature revealed eight key dimensions. Quite apart from the conventional 
population threshold of 5,000 people, the paper finds that data on the urban form, the extent of the built-up area, the land-use dynamics, socio-economic functions, and occupational, governance and housing structures, could also be used to classify a settlement as urban.

Whilst admitting that some of these dimensions cannot be directly measured, the paper suggests that detecting and analyzing land use dynamics from satellite-based remote sensing data and techniques, various spatial and statistical data on the aforementioned dimensions can be derived. Combining advanced satellite imagery with ground truth-gathered data, as well as in algorithm development, could allow analysts and urban planners to classify urban areas in a timely manner with frequent updates.

Overall, the findings of this paper contribute to a better understanding of how urban settlements can be classified by using a multi-dimensional approach as a feasible alternative. It also offers an insight to the Ghana statistical service to "think out of the minimum population threshold box" and to begin to consider the heterogeneity and multiple attributes characterizing the areas of new growth, especially the urban "villages" on the periphery of cities. Future studies should thus focus on developing remote sensing algorithms that can infer the proposed dimensions from physical land features. It is also important to develop indices for each dimension to aid in the classification of urban areas.

\section{References}

ADAM A. G. (2014), Land Tenure in the Changing Peri-Urban Areas of Ethiopia: The Case of Bahir Dar City, International Journal of Urban and Regional Research 38 (6), 19701984.

ANGEL S., BLEI A. M., PARENT J., LAMSON-HALL P., SÁNCHES N. G., CIVCO D. L., QIAN LEI R., THOM K. (2016), Atlas of Urban Expansion 1: The 2016 Edition. Areas and Densities, New York University, New York, UN-Habitat, Nairobi, Lincoln Institute of Land Policy, Cambridge, MA.

APPIAH D. O., FORKUO E. K., BUGRI J. T., APREKU T. O. (2017), Geospatial Analysis of Land Use and Land Cover Transitions from 1986-2014 in a Peri-Urban Ghana, Geosciences 7 (4), 125.

APPIAH D. O., SCHRÖDER D., FORKUO E. K., BUGRI J. T. (2015), Application of Geo -Information Techniques in Land Use and Land Cover Change Analysis in a Peri-Urban District of Ghana, ISPRS International Journal of Geo-Information 4 (3), 1265-1289.

ASIEDU A. B., ARKU G. (2009), The rise of gated housing estates in Ghana: Empirical insights from three communities in metropolitan Accra, Journal of Housing and the Built Environment 24, 227-247.

BAKER J., PEDERSEN P. O. (eds.) (1992), The rural-urban interface in Africa: Expansion and Adaption, Nordiska Afrikainstitutet, Uppsala, Centre for Development Research, Copenhagen.

BAWAKYILLENUO S., OSEI AKOTO I., AHIADEKE C., ARYEETEY E. B.-D., AGBE E. K. (2013), Tertiary Education and Industrial Development in Ghana, International Growth Centre, Retrieved from: www.theigc.org.

BENZA M., WEEKS J. R., STOW D. A., LÓPEZ-CARR D., CLARKE K. C. (2016), A pattern-based definition of urban context using remote sensing and GIS, Remote Sensing of Environment 183, 250-264.

BHATTA B. (2010), Analysis of Urban Growth and Sprawl from Remote Sensing Data, Springer, Berlin, Heidelberg.

BLOCH R., FOX S., MONROY J., OJO A. (2015), Urbanisation and Urban Expansion in Nigeria, Urbanisation Research Nigeria (URN), London. 
CITIES ALLIANCE (2017), Urban Governance and Services in Ghana: Institutional, financial and functional constraints to effective service delivery, Cities Alliance, Retrieved from: www.citiesalliance.org.

COBBINAH P. B., ERDIAW-KWASIE M. O. (2016), Urbanization in Ghana: Insights and Implications for Urban Governance, in: Benna U. G., Garba S. B. (eds.), Population Growth and Rapid Urbanization in the Developing World, IGI Global, Hershey, pp. 82-104.

COLOMB C., RACO M. (2015), Planning for / in the super-diverse city: between celebratory policy narratives and the reality of planning policies in London, RC21 International Conference on "The Ideal City: between myth and reality. Representations, policies, contradictions and challenges for tomorrow's urban life", Retrieved from: www.rc21.org.

DEUSKAR C. (2015), What does "urban" mean?, World Bank, Retrieved from: www.blogs.worldbank.org.

DIJKSTRA L., POELMAN H. (2014), A harmonised definition of cities and rural areas: the new degree of urbanisation, European Commission, Retrieved from: www.ec.europa.eu.

DOAN P., ODURO C. Y. (2012), Patterns of Population Growth in Peri-Urban Accra, Ghana, International Journal of Urban and Regional Research 36 (6), 1306-1325.

DODIER R. (2013), Modes d'habiter périurbains et intégration sociale et urbaine, EspacesTemps.net.

DONNAY J.-P., BARNSLEY M. J., LONGLEY P. A. (eds.), (2001), Remote Sensing and Urban Analysis, CRC Press, London.

ELMQVIST T., BAI $X$., FRANTZESKAKI N., GRIFFITH C., MADDOX D., MCPHEARSON T., PARNELL S., ROMERO-LANKAO P., SIMON D., WATKINS M. (eds.) (2018), Urban Planet: Knowledge towards Sustainable Cities, Cambridge University Press, London.

ESTES L., CHEN P., DEBATS S., EVANS T., FERREIRA S., KUEMMERLE T., RAGAZZO G., SHEFFIELD J., WOLF A., WOOD E., CAYLOR K. (2018), A large-area, spatially continuous assessment of land cover map error and its impact on downstream analyses, Global Change Biology 24 (1), 322-337.

GAMBA P., HEROLD M. (eds.) (2009), Global Mapping of Human Settlement: Experiences, Datasets, and Prospects, CRC Press, London.

GHANA STATISTICAL SERVICE (2014), Urbanization in Ghana: 2010 Population and Housing Census Report, Retrieved from: www.statsghana.gov.gh.

GOUGH K. V., ANDREASEN M. H., ESSON J., MAINET H., NAMANGAYA A. H., YANKSON P. W. K., AGERGAARD J., AMANKWAH E., KIUNSI R., MØLLER $\square$ JENSEN L., YEMMAFOUO A. (2015), City Dynamics: Mobility and Livelihoods of Urban Residents, RurbanAfrica, Retrieved from: www.rurbanafrica.ku.dk.

GOUGH K., YANKSON P. (2006), Conflict and cooperation in environmental management in peri-urban Accra, Ghana, in: McGregor D., Simon D., Thompson D. (eds.), The Peri-Urban Interface: Approaches to Sustainable Natural and Human Resource Use, Earthscan, Abingdon, pp. 196-210.

GOUGH K. V., YANKSON P. (2011), A Neglected Aspect of the Housing Market: The Caretakers of Peri-urban Accra, Ghana, Urban Studies 48 (4), 793-810.

GOUGH K. V., YANKSON P. W. K. (2000), Land Markets in African Cities: The Case of Peri-urban Accra, Ghana, Urban Studies 37 (13), 2485-2500.

GRIFFITHS P., HOSTERT P., GRUEBNER O., VAN DER LINDEN S. (2010), Mapping Megacity Growth with Multi-Sensor Data, Remote Sensing of Environment 114 (2), 426-439.

KAUFMANN H., FÖRSTER S., WULF H., SEGL K., GUANTER L., BOCHOW M., HEIDEN U., MÜLLER A., HELDENS W., SCHNEIDERHAN T., LEITÃO P. J., VAN DER LINDEN S., HOSTERT P., HILL J., BUDDENBAUM H., MAUSER W., HANK T., KRASEMANN H., RÖTTGERS R., OPPELT N., HEIM B. (2016), Science Plan of the Environmental Mapping and Analysis Program (EnMAP), EnMAP, Retrieved from: www.gfzpublic.gfz-potsdam.de.

HANSEN M. H, HURWITZ W. N, PRITZKER L. (1953), The Accuracy of Census Results, American Sociological Review 18 (4), 416-423. 
IOSSIFOVA D., DOLL C. N. H., GASPARATOS A. (eds.) (2018), Defining the Urban: Interdisciplinary and Professional Perspectives, Routledge, London.

KEIL R. (2018), Suburban planet: Making the world urban from the outside in, Polity Press, Cambridge.

KLEEMANN J., INKOOM J. N., THIEL M., SHANKAR S., LAUTENBACH S., FÜRST C. (2017), Peri-urban land use pattern and its relation to land use planning in Ghana, West Africa, Landscape and Urban Planning 165, 280-294.

KORCELLI-OLEJNICZAK E. (2017), EU 7 FP project. Governing urban divercity: creating social cohesion, social mobility and economic performance in today's hyper-diversified cities (DIVERCITIES) - the case of Warsaw, Geographia Polonica 90 (2), 123-129.

MAHENDRA A., SETO K. C. (2019), Upward and Outward Growth: Managing Urban Expansion for More Equitable Cities in the Global South, World Resources Institute, Retrieved from: www.wri.org.

MOEHL J. J., ROSE A. N., BRIGHT E. A. (2016), Spatializing Global Urban Extent: A Source Driven Approach, International Conference on GIScience Short Paper Proceedings, 203-207.

MØLLER-JENSEN L., ALLOTEY A. N., KOFIE R. Y., YANKSON P. W. K. (2020), A Comparison of Satellite-Based Estimates of Urban Agglomeration Size for the Accra Area, ISPRS International Journal of Geo-Information 9 (2), 79.

MOLLER-JENSEN L., KNUDSEN M. H. (2008), Patterns of population change in Ghana (1984-2000): urbanization and frontier development, GeoJournal 73, 307-320.

MORICONI-EBRARD F., HARRE D., HEINRIGS P. (2016), Urbanization Dynamics in West Africa 1950-2010: Africapolis I. 2015 Update, OECD Publishing, Paris.

NAAB F. Z., DINYE R. D., KASANGA R. K. (2013), Urbanisation and its impact on agricultural lands in growing cities in developing countries: A cast study of Tamale in Ghana, Modern Social Science Journal 2 (2), 256-287.

ODURO C. Y., ADAMTEY R., OCLOO K. (2015), Urban Growth and Livelihood Transformations on the Fringes of African Cities: A Case Study of Changing Livelihoods in Peri -Urban Accra, Environment and Natural Resources Research 5 (2), 81-98.

ODURO C. Y., OCLOO K., PEPRAH C. (2014), Analyzing Growth Patterns of Greater Kumasi Metropolitan Area Using GIS and Multiple Regression Techniques, Journal of Sustainable Development 7 (5), 13-31.

OWUSU G. (2005), Small Towns in Ghana: Justifications for their Promotion under Ghana's Decentralisation Programme, African Studies Quarterly 8 (2), 48.

OWUSU G. (2008), The Role of Small Towns in Regional Development and Poverty Reduction in Ghana, International Journal of Urban and Regional Research 32 (2), 453-472.

OWUSU G. (2013), Coping with urban sprawl: a critical discussion of the urban containment strategy in a developing city, Accra, Planum: The Journal of Urbanism 26 (1), 117.

OWUSU G. (2015), Decentralized Development Planning and Fragmentation of Metropolitan Regions: The Case of the Greater Accra Metropolitan Area, Ghana, Ghana Journal of Geography 7 (1), 1-24.

PITTER J., LORINC J. (eds.) (2016), Subdivided: City-building in an age of hyperdiversity, Coach House Books, Toronto.

POTTS D. (2018), Urban data and definitions in sub-Saharan Africa: Mismatches between the pace of urbanisation and employment and livelihood change, Urban Studies 55 (5), 965-986.

RASHED T., JÜRGENS C. (eds.) (2010), Remote Sensing of Urban and Suburban Areas, Springer, London.

RICKARDS L., GLEESON B., O'CALLAGHAN C., BOYLE M. (2016), 'The urban': a concept under stress in an interconnected world, The Conversation, Retrieved from: www.theconversation.com. 
SAHEL AND WEST AFRICA CLUB (2020), Africapolis, SWAC, Retrieved from: www.africapolis.org.

SCHMID C., KARAMAN O., HANAKATA N. C., KALLENBERGER P., KOCKELKORN A., SAWYER L., STREULE M., WONG K. P. (2018), Towards a new vocabulary of urbanisation processes: A comparative approach, Urban Studies 55 (1), 19-52.

SCHNEIDER A., WOODCOCK C. E. (2008), Compact, Dispersed, Fragmented, Extensive? A Comparison of Urban Growth in Twenty-five Global Cities using Remotely Sensed Data, Pattern Metrics and Census Information, Urban Studies 45 (3), 659-692.

SETO K. C, REENBERG A. (eds.) (2014), Rethinking Global Land Use in an Urban Era, The MIT Press, London.

SETO K. C., REENBERG A., BOONE C. G., FRAGKIAS M., HAASE D., LANGANKE T., MARCOTULLIO P., MUNROE D. K., OLAH B., SIMON D. (2012), Urban land teleconnections and sustainability, PNAS 109 (20), 7687-7692.

SONGSORE J. (2009), The Urban Transition in Ghana: Urbanization, National Development and Poverty Reduction, University of Ghana, Retrieved from: www.pubs.iied.org.

STOW D. A., WEEKS J. R., SHIH H.-C., COULTER L. L., JOHNSON H., TSAI Y.-H.,

KERR A., BENZA M., MENSAH F. (2016), Inter-Regional Pattern of Urbanization in Southern Ghana in the First Decade of the New Millennium, Applied Geography 71, 32-43.

SZABO S. (2016), Urbanisation and Inequalities in a Post-Malthusian Context:

Challenges for the Sustainable Development Agenda, Springer, New York.

TASAN-KOK T., VAN KEMPEN R., RACO M., BOLT G. (2013), Towards Hyper-

Diversified European Cities: A Critical Literature Review, Utrecht University, Utrecht.

UCHIDA H., NELSON A. (2009), Agglomeration index: Towards a new measure of urban concentration, World Bank, Washington, DC.

UNITED NATIONS (2018), The 2018 Revision of World Urbanization Prospects,

Department of Economic and Social Affairs, Retrieved from: www.population.un.org.

VERTOVEC S. (2007), Super-diversity and its implications, Ethnic and Racial Studies

30 (6), 1024-1054.

VORMANN B. (2015), Urban Diversity: Disentangling the Cultural from the Economic

Case, New Diversities 17 (2), 119-129.

WEEKS J. R. (2010), Defining Urban Areas, in: Rashed T., Jürgens C. (eds.), Remote

Sensing of Urban and Suburban Areas, Springer, London, pp. 33-45.

WORLD BANK GROUP (2015), Rising through Cities in Ghana: Ghana Urbanization

Review Overview Report, World Bank, Washington, DC.

YEBOAH I. E. A., CODJOE S. N. A., MAINGI J. K. (2013), Emerging urban system demographic trends: informing Ghana's national urban policy and lessons for Sub-Saharan Africa, Africa Today 60 (1), 98-124.

Initial submission: 09.05.2019

Revised submission: 07.04.2020

Final acceptance: 29.05 .2020

Correspondence: Governance \& Sustainability Lab, Faculty VI - Regional and Environmental Sciences, Campus II, Trier University, D - 54286 Trier, Germany.

Email: akubia@uni-trier.de 
